\title{
OLD AGE - „HOW BEAUTIFUL TO BE YOURSELF”
}

\author{
ILONA ZAKOWICZ \\ ilona.zakowicz@wp.pl
}

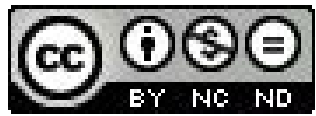

\begin{abstract}
In every given period one can observe different attitudes towards old age, death and the elderly, which are shown through varied stances and ideas about this specific period of human life. The reality of the XXI century often regarded as "vision-centric" is dominated by the cult of beauty and youth which creates increasingly demanding requirements, related mainly to the attractiveness of appearance, of the body - especially the one belonging to the elderly. The increase in the number of senior citizens compared to the rest of the society that can be witnessed nowadays leads to the elderly being a more carefully examined social group. Mediated by the media discourse the images of the elderly are becoming more common and therefore the author's attempt at reconstructing the postmodern strategy of the rendering of late adulthood seems to be an interesting and important topic to consider.

Key words: old age, elderly, body, advertisement, appearance, aestheticization.

"Ageing has been removed from common imagination. Inadequate for faustian axioms of modern times, limp bodies haunt only the retirement houses. Mass culture is dominated by young, preferably naked and in-shape bodies: "Youth forever naked! Nudity forever young! «"
\end{abstract}

(Czaja 1994, p. 149)

The renaissance of old age, up until now only a speculation, slowly yet surely becomes a fact. It can be argued that in some sense a "trend for old age" is arising. The concept of old age is the topic of many contemporary discussions focusing on its economic, social, cultural and demographic aspects. It is a field of study for both the scientists and the general public, in short, as Jean Pierre Bois stated - old age is a hot topic now - it is omnipresent (Bois 1996, p. 11). This phenomenon of the popularity of old age is not augmented by the qualitative change in the ageing discourse, on the contrary - it becomes a shameful and in a way problematic subject. It is treated as a disease or a punishment for lack of care of one's body, it is pushed to the margin.

The older years are a period of human life that is characterized by a lot of variety. Therefore in order to capture its meaning one needs to consider that it eludes any attempt at generalization while also keeping a keen eye on specificity of participation, description and presentation of it. Old age, despite being always present and unavoidable, has been covered by a thick layer of prejudice and misinterpretation, which contributed to the perception of one's elder years as unattractive. A period during which "losses outweigh gains" and defects, usually bodily, become more prominent. It is hard to ignore the fact that old age is quite often reduced to its bodily effects, it is identified with menopause, andropause and climacterium. It is willfully put in the same context as countless diseases and illnesses (conditions transforming the body into a constantly ticking time bomb, 
a Pandora's box, sealed tight for so long yet with passing years and advent of old age becoming a source of worry). Old age becomes the "curse" of a man trapped in a cage of his own degrading body.

Considering old age only as a bodily process has led in consequence to a simplified, reduced image of old age to health and appearance, a shameful illness which should be hidden or treated. A condition that should not be shown in order to maintain esthetic and psychic comfort of society, quite the contrary - it should be thrown in the closet like an outdated dress from a bygone era. The body of an old man is treated as "invisible", it is not accepted and therefore in a sense "transparent".

It is interesting that ageing reduced to only physical changes is no longer considered a natural phenomenon which leads to visible body surface changes being treated as a symptoms of negligence. All kinds of signs of ageing and especially those which alter appearance are considered unacceptable - not fitting the idea of "aestheticization of daily life" and as a consequence a more and more aggressive fight is carried out against them. It is important to notice that the disturbing word "fight" is not used here by accident. Analysis of media offerings, especially advertisements for cosmetics occurring in press (and internet) directed towards women allows one to form a thesis that the terminology used by mass media to address an ageing body is related to aggression, power and maintaining control. It is the language of oppression, calling for a specific form of self-aggression whose goal is the obtaining of the perfect appearance. Examples of phrases that encourage disciplining the ageing body can be primarily found in adverts for cosmetics "created to combat the first signs of ageing skin"2 (http:/ / www.avene.com.pl/dermokos. php?dnavi $=6 \& \mathrm{pm}=\mathrm{p}$-ystheal\&ind $=0$ ). Those products also "fight everyday with 7 signs of ageing skin" (http://ibeauty.pl/artykuly,146,148,2298, polecamyna-prezent-zestawy-olay-total-effects) and if that does not help one could try "strongly rejuvenating procedure exploiting beneficial features of caviar" (http:// www.cogiel-medicalspa.pl/oferta/pielegnacja-ciala/,) because "it is never too late to declare war on wrinkles, even the deepest ones!"(Nieinwazyjna kuracja odmładzająca bezpieczniejsza od zastrzyków i chirurgii plastycznej).

Parties responsible for creating commercials as can be clearly seen are becoming more aggressive in their fight for their share of the market and in the XXI century they have found an almost perfect target group - the elderly. Propagating the idea that good looks are an appropriate solution to any problem they have created a market which allows for the establishment of immense corporations deriving their profit from fear and frustration of those who cannot come to terms with "grey-haired" appearance. The threat of "invisibility" in public space, marginalization and lack of social acceptance are all factors which contribute to urging the elderly to struggle to recreate their appearance according to standards, expectations and models propagated by society. The necessity to constantly update one's physical being, its permanent redefinition, is not an easy task to accomplish. On the contrary - many procedures designed to "regain bodies lost" to ageing seem only to amplify the feelings of inadequacy and displacement. This inadequacy is

\footnotetext{
2 All translations by the author unless stated otherwise.
} 
derived from denying the process of ageing, searching for more attractive ways of maintaining one's physical appearance, transforming the body into a plastic and open space - vulnerable to change and suggestion of all kinds. Appearance nowadays is no longer a matter of one's choice but rather a necessity augmented and reinforced by the pantheon of ideal images presenting perfect bodies inhabiting a colorful, rejuvenated, always attractive land of youth and happiness, a land created by mass media for the pleasure of the audience.

The first symptoms of ageing usually become apparent on the body. It is the first warning sign that youth and beauty - the most important values for contemporary homo esteticus - are passing. Wrinkles, grey hair and skin discoloration are beginning to show and along with them comes the anxiety, which is not only based on the fear of physical ageing and death but also on the fear of being marginalized. Growing as the time goes by this fear can be interpreted in different ways. It is an important factor in many contexts: social, cultural, and economic becoming in the end the dominant feeling of a person. As such it influences the elderly person's existence on many different levels, affecting their quality of life and perception of the surrounding world.

This fear, somehow "imprinted" in ageing people's minds, is augmented by mass media and their "cult of youth" which leads to enhancing the feelings of danger derived from fear of being denied social visibility and loosing one's social standing. It seems reasonable to agree with George Minois, who claimed that old age is a term that "sends shivers down one's spine, it is filled with anxiety, weakness and sometimes fear" (Minois 1995, p. 11). The term being not precise, which meaning still eludes clear definition, a fraction of reality whose borders are difficult to define (Minois 1995, p. 11), for generations has evoked varied, sometimes contradictory feelings, which seems to concur with the current growth of interest in this particular period of life in mass media, politics and the general public. Due to the increase in numbers of senior citizens in western societies, they are, as a group, more closely examined by both the researchers representing different fields of study and business entities which, no longer ignore them as consumers and start to see this group as a potential market for their goods and services.

Old age, up until now ignored by mass media by default, is getting more attention. It is often discussed, written about, shown on television, in movies, magazines, advertisements. Senior citizens became "visible" in the public space, they are no longer a specific social subcategory, the so-called "post productive age", on the contrary they become the regulars in cafés, cinemas, beauty shops, dance clubs and many other establishments, which, as can be theorized, will adjust their services to comply with needs and expectations of the ageing society. It is also true that senior citizens, due to their large numbers, are influencing at an increased rate the shape of social life yet still stereotypes about old age and the elderly, deeply rooted in many Europeans' minds are functioning and do not show the signs of weakening. Reproduced and enhanced by mass media they are treated as axioms, which in an undeniable way influence the ways of portraying the late adulthood period and augment it's marginal location in society.

It is not exactly a new idea that we live in society dominated by "cult of youth" 
and "terror of beauty" which can be observed in widely distributed images of bodies: young, well-cared for, beautiful and attractive. Bodies disciplined and processed, resembling in a way works of art. Bodies whose image is not by any way random, in fact it is the opposite - it is planned, created and modified to the fullest possible extent, whose ends are set by the limitations of body and social norms, never failing in its search for more and more creative images of what the ancient Greeks dubbed soma. As Wojciech Klimczyk correctly states: "postmodernism puts the body in the centre of attention" (Klimczyk 2008, p. 99), in effect it becomes a specifically understood area of social and cultural influence. It is impossible to ignore the omnipresence of its images. Endlessly reproduced in the form of photograph, advertisement, and works of art it becomes a symbol of the aforementioned "terror of beauty" based on promoting young bodies, healthy, active and aesthetically attractive. The currently observable specific type of obsession - the "body obsession" - enhances the process of changing the status of the body both in culture and in society. It becomes - as pointed out by Zygmunt Bauman - "primarily an organ of consumption and the point of reference for its proper condition is the ability to absorb and assimilate everything that the consumer society has to offer" (Bauman 1995, p. 90). In this way soma becomes in a way an instrument through which the world is experienced, the contemporary human "experiences the world by consuming it" (Klimczyk 2008, p. 102). This specific consumption performed by the body can obviously be interpreted in many different ways, it is important though to remember that the "consuming" body is also being "consumed" (is "consumed" by other bodies) and becomes in a way a "product" entangled in the free commerce sphere.

The body is a complex socio-cultural construct and as such it should adapt to currently accepted norms and rules because if it is not able to "adapt to cultural expectations it becomes a source of suffering and frustration due to social marginalization" (Klimczyk 2008, p. 98). The process of adaptation to current standards affects mainly women, as Edyta Zierkiewicz and Izabela Kowalczyk said appearance becomes a "primary feature defining the identity of woman. Women are taught to perceive themselves as objects seen by the others" (Zierkiewicz, Kowalczyk 2002, p. 119). Therefore every woman feels like "a participant in a way of a beauty contest in which every other woman is her rival. Never mind how non influential it is for her goals, inadequate next to her talents or just how laughable is the comparison, women are always compared to each other and it always shows that in some areas they are lacking"(Etcoff 2000, p. 95-96). Due to this fact it is hard not to notice that companies, corporations and other business entities whose products are the dreams of perfect appearance are trying more and more bravely to invade the imagination of consumers with images of ideal bodies through more or less sophisticated methods created by the marketing and advertisement specialists. The contemporary alchemists - searching for and discovering the cures for any and all ailments including ageing, which is being treated as a specific yet incurable disease. The impudence of those companies does not stop there. Manufacturers and creators of advertisements engage in reckless attempts to create "the elixir of youth". Trying to complete the timeless quest for immortality they 
proclaim from time to time a lesser or greater victory which, in theory, bring mankind closer to that unachievable dream. How can one doubt those bold statements when almost all major women's magazines contain catchphrases such as the one used by L'Oreal Paris: be " always young with L'Oreal Paris - because you're worth it"(http://www.lorealparis.pl/_pl/_pl/home/index.aspx).

Female bodies are constantly examined, compared and graded. Women since childhood observe, admire and mimic other women. It should not come as a surprise then that women put a lot more effort into maintaining youthful, attractive appearance. Tormenting themselves over various imperfections, which in turn is successfully used by advertisement agencies that exercise any option open to them to persuade the women that caring for themselves - understood as preventing ageing, rejuvenating - is their duty. Failure to uphold this duty may even be identified with the "sin of acedia" or in the best case - a symptom of irresponsibility or lack of will, motivation. This can be seen in common opinion promoted in various guides for women, stating that: "before 35 years of age woman has the face that nature has given her while after turning 35 she has the face she worked for" (Zielono mi ...!). Hence caring for one's appearance is a consciously chosen strategy, whose goal is to take control over the body: removing wrinkles, grey hairs, counting the calories, using various diets, concoctions and balms.

The body experience, when keeping old age as a point of reference, seems to be based on permanent control, necessity to constantly adjust to social expectations, lack of acceptance and in a way denying one's own physicality enacted through constant negation of it. The body of an elder person can be seen as an old, forgotten, longtime unused instrument which requires proper tuning to harmonize with the dominant melody - the cult of youth. Increased level of control that contemporary society exercises over the individual body renders in a way its appearance as a public matter. It is transformed into a homogenous and deprivatized item which is increasingly susceptible to influences and expectations of esthetically oriented society. It seems reasonable that soma reduced only to its surface is not given to a human but it is rather a task to accomplish, an esthetic-visual project (even, or maybe especially when the body belongs to an elder person).

Postmodernism, as W. Klimczyk says, "is a period of aestheticization and exaltation, that is - searching throughout life for the possibility to experience it at the utmost" (Klimczyk 2008, p. 62), time when only that which is "esthetically correct" - directed towards sensual perception matters. Society of the XX/XXI century is a society of images which more commonly serve to shape human sensibility and perception of the world. Society in awe of young and beautiful bodies tries to forget eschatology and the sorrowful reality of ageing and death. In order to achieve these goals public space (and daily life) is purged of everything that reminds of passing of the body: ageing, illnesses, disabilities and death. In the XXI century the body becomes an esthetically directed "enterprise", which denies phenomena such as ageing because any "deviations from esthetic norm" are perceived as "pathology" that should be marginalized, hidden or remodelled. As W. Klimczyk notes in postmodernism "bad is that which looks bad" (Klimczyk 2008, p. 64), therefore old age, invoking the images of an old, weakening body should be beau- 
tified or kept under lock and key in hospitals, hospices, or retirement homes. It does not fit in with the context of the period determined by temporariness, spontaneity, beauty and youth therefore it must undergo a dramatic change thanks to which it will be camouflaged or hidden under the thick layer of make-up, anti wrinkle cream, balm or hair dye. "softened", "removed", "sucked" by plastic surgeons, "dressed up" by stylists and "cured" by medical doctors so that it may cease to scare with the vision of unattractiveness and in the end - mortality.

Magdalena Środa correctly notices that nowadays there should not be any old people because we have in our hands "all the means and especially every hope for everlasting youth and even - physical immortality. Currently everything can be trimmed, lifted, sucked, tied, painted over, covered, masked, enriched, massaged, moisturized, replaced, thinned, realigned, glued" (Środa 2000, p. 2). The body is fast becoming a negotiating table, a matter of choice more or less intentional or considered, hence its permanent reconstruction can not be a random incident.

The body and its appearance are the most outward and visible part of one's personality, it is an area exposed to public scrutiny and critique, a medium through which changes occurring inside the body are made visible on its surface. The body is the part that ages, contracts diseases, weakens, slowly dies, its form and shape being modified to signal disturbing changes recalling death which is currently considered taboo. It is important to consider that even though ageing visibly manifests itself on the body, it is a process involving a person as a whole - a psycho-physical entity that can not be reduced to its biological elements only. Therefore the ageing process of a human being (an ontologically differentiated entity) due to its nature should be considered on two ontological levels: physical and psychic. This fact seems to be forgotten by the mass media which form the context for this work.

The phenomenon of ageing as is commonly known is effected on the level incorporating both nature and culture - the goal of which is "a task not freely chosen, to preserve the contingency" (Bauman 1998, p. 31) of human life. It is a fact of dual nature - its basic level is biological but it is clothed in a "cultural vestment". Thanks to culture its many representations come into being, which in turn are a source of inspiration for the media that never cease to search for more and more "attractive" ways of portraying old age. This process of rendering symptoms of ageing as more attractive focuses primarily on the "usage" of the body in a way that it would gain a socially accepted appearance. Media, as is commonly known, at the same time reflect and create culture, they do not present the world as it is but try to construct it by associating with its elements meanings of their choosing. This leads to old age, among others, being mediated by the media discourse. It is important to notice that it is a specific representation of old age, processed, subjected to facelift, aestheticitized and rejuvenated, in other words - tailored to suit the expectations of modern world.

Encounters with images are a fundamental experience for a human in the XXI century. Those encounters are regulated by the market, which - as W. Klimczyk observed - must lead to practical consequences (Klimczyk 2008, p. 63-64). The manipulation of images that can be observed, among others, in advertisements 
creates a situation where human needs are constantly redefined, especially those focusing on the physical appearance. Mass media fuel desires and expectations of the audience up to breaking point, persuading at the same time that when it comes to one's body everything is possible. The body in the media discourse is perceived as a surface that can be written, modeled and created in every possible way. Appearance is interpreted as a way in which one individual body wants to be perceived by other bodies. It is not without reason that mass media constantly inspire both male and female expectations of body, implying that anything (and for everyone) is in this case possible and it only takes a strong will and inclination. Esthetically oriented postmodernism demands that the human acknowledges his body as a specific "project" which requires constant effort and work directed towards transforming it into a "work of art" because, as W. Klimczyk states the "body should be always ready to be presented" (Klimczyk 2008, p. 109) since the number of glances filled with desire is the factor measuring its success.

Old age perceived mainly from the physical point of view seems to be a specific problem. At the same time noticed by the media and commerce it serves to transform the elderly into a valuable consumer group, whose potential has not yet been fully exploited.

It may be nothing new to state that the increased interest of advertisement agencies in image and status of the senior citizens is the effect of economic calculation rather than of care for quality of their life. The idea of maintaining the body in good physical condition is nowadays a powerful branch of the industry deriving immense profit from the elderly unsatisfied with their appearance and health. This thesis is supported by Nancy Etcoff who said that "nowadays an average woman compares her features, inherited from her ancestors, with a few carefully chosen models. Despite the fact that their beauty is unreal the media convince us that we can achieve their beauty if we only put a lot of effort into it, undergo adequate procedures and buy certain products" (Etcoff 2000, p. 97). Therefore it seems reasonable to claim that the greater the tenacity and awareness of the changing trends, the higher the probability of success, which measurement is directly related to the necessity of constantly updating the appearance, ongoing redefinition of physicality adjusted to ever changing formulas.

Even the superficial analysis of the commercials broadcasted through the mass media allows for formulation of thesis that one of the ways to present the old age is its identification with the physical body or some of its parts: " 40 years have passed... and you still feel young. Your skin can also stay light and soft" - be "always young with L'Oreal", "fight with the loss of firmness and visible wrinkles", because "after 50 skin becomes less moisturized, its structure looses firmness, and the complexion is less homogenous. New revitalizing cream for day use Garnier Orchidea Vital combats the main visible symptoms of ageing. Every day the deeper levels of skin are moisturized which gives the skin a light and rebuilt look. Women notice changes after just 4 weeks of usage" (http:/ / e-styl.com/p/ pl/5486/ garnier+orchidea+vital++wiek+50+krem+rewitalizujacy+na+dzien+5 $0+\mathrm{ml} . \mathrm{html}$ ). The body multiplied in mass media appears to be an uncommonly plastic item, ready to receive various signals that the individual gathers, assimi- 
lates, consumes. It is a specific medium, a surface serving as a negotiating table for the outside world and the inner self.

Images of bodies undergoing natural ageing are more and more strongly marginalized, almost banned from consciousness and imagination. Only those presentations are approved for public view which show old age as full of life and active. As an effect of this, bodies showing signs of ageing are treated as being out of control and is a potential threat - "it entices moral, legal and esthetic forces whose task is to discipline it" (Fiske 2010, p. 73). The body, as Z. Bauman claims "is nowadays, in a non-disputable manner, a "private property «. Caring for it, as with a garden, is solely the owner's affair. There is nobody to blame except the owner if the garden is overgrown with weeds, soil is not fertilized and there's no water in the water-can (...). Having gained his body as a private property the owner got himself into a lot of trouble. He is the garden and the gardener at the same time" (Bauman 1995, p. 94).

\section{BIBLIOGRAPHY}

Bauman Z. (1995), Ciało i przemoc w obliczu ponowoczesności, UMK, Torun.

Bauman Z. (1998), Śmierć i nieśmiertelność. O wielości strategii życia, PWN, Warszawa.

Bois J. P. (1996), Historia starości od Montaignéa do pierwszych emerytur, Oficyna Wydawnicza Volumen, Warszawa.

Czaja D. (1994), Reklamowy smak raju: między archetypem i historia, [in:] Czaja D. (ed.), Mitologie popularne, Universitas, Kraków.

Etcoff N. (2000), Przetrwają najpiękniejsi. Wszystko, co nauka mówi o ludzkim pięknie, WAB, Warszawa.

Fiske J. (2010), Zrozumieć kulturę popularna, Wydawnictwo Uniwersytetu Jagiellońskiego, Kraków.

Klimczyk W. (2008), Erotyzm ponowoczesny, Universitas, Kraków.

Minois G. (1995), Historia starości. Od antyku do renesansu, Oficyna Wydawnicza Volumen, Warszawa. Zierkiewicz E., Kowalczyk I. (2002), Konsumentka czy konsumowana? Kobieta do zjedzenia w prasie kobiecej, „Kultura Popularna” 0.

\section{NETOGRAPHY}

http:/ /e-styl.com/p/pl/5486/garnier+orchidea+vital++wiek+50+krem+rewitalizujacy+na+dzien+5 0+ml.html, retrieved: 12.02.2012.

http:/ /ibeauty.pl/artykuly,146,148,2298,polecamy-na-prezent-zestawy-olay-total-effects, retrieved: 20.02.2012.

http:/ / www.avene.com.pl/dermokos.php?dnavi=6\&pm=p-ystheal\&ind=0, retrieved: 20.02.2012.

http://www.cogiel-medicalspa.pl/oferta/ pielegnacja-ciala/, retrieved: 20.02.2012.

http://www.lorealparis.pl/_pl/_pl/home/index.aspx, retrieved: 20.02.2012.

Nieinwazyjna kuracja odmładzająca bezpieczniejsza od zastrzyków i chirurgii plastycznej, http:/ / frownies.pl/ frownies.html, retrieved: 20.02.2012.

Środa M. (2000), Nie udo, ale gałąź sucha, „Biuletyny Oski” 4, http:/ / www.oska.org.pl/biuletyn/10/96. pdf, retrieved: 15.02.2012.

Zielono mi ...!, http://ekozdrowie.blog.onet.pl/Jak-walczyc-ze-staroscia,2,ID421960627,n, retrieved: 20.02.2012. 